\title{
Pelatihan dan Pendampingan Pemeliharaan Ikan Lele Guna Meningkatkan Omzet Penjualan di Desa Kanigoro Kabupaten Malang
}

\author{
Asroful Anam1, Arif Kurniawan', Teguh Rahardjo² \\ 'Departemen Teknik Mesin, '2Departemen Teknik Geodesi, Institut Teknologi Nasional Malang \\ Jl. Bendungan Sigura-gura No. 2 Malang, 65152, Indonesia
}

\begin{abstract}
ARTICLE INFO
Received: 2021-01-10

Revised: 2021-02-16

Accepted: 2021-03-25

Keywords:

Catfish farmers,

Income, Seeds

ABSTRACT

Prosperous sociaty in terms of livelihoods and having high income to fulfill all their needs are absolute desires, so they can avoid poverty, especially for people in rural areas whose lives depend on livestock farming, such as fish farmers. To avoid poverty, people need a program to be developed their knowledge and insight, with the aim of increasing their business income, as was done by a group of catfish farmers in Kampung Coban, Desa Kanigoro, Kecematan Pagelaran, Kabupaten Malang. Improving the knowledge and insight refered to solve their problems faced, namely the high of production and long harvest period; lack of knowledge and skills on how to select superior seeds and seedlings; and the lack of knowledge and skills in profitable business management. The program activities used social interactive methods in the form of coaching or mentoring and designing their own feed making tools. Based on the results of the activities of using tools and guidance, the catfish farmers can make their own feed mixed with factory feed, and increase the income.
\end{abstract}

(C)2021 Published by University of Merdeka Malang. This is an open access article distributed under the CC BY-SA 4.0 license (https://creativecommons.org/licenses/by-sa/4.0/)

How to cite: Anam, A., Kurniawan, A., \& Rahardjo, T. (2021). Pelatihan dan Pendampingan Pemeliharaan Ikan Lele Guna Meningkatkan Omzet Penjualan di Desa Kanigoro Kabupaten Malang. Abdimas: Jurnal Pengabdian Masyarakat Universitas Merdeka Malang, 6(2), 251-259. https://doi.org/10.26905/abdimas.v6i2.52854

\section{PENDAHULUAN}

Masyarakat yang sejahtera dalam penghidupan dan memiliki pendapatan yang layak dalam memenuhi seluruh kebutuhan baik primer dan sekunder merupakan keinginan mutlak, agar bisa terhindar dari kemiskinan baik bagi masyarakat yang dipedesaan maupun di perkotaan (Nawangsih, 2018). Berdasarkan data Badan Pusat Statistik atau BPS mencatat angka kemiskinan pada September 2019 mencapai 9,22\%. Angka ini turun 0,19\% poin terhadap Maret 2019 dan menurun 0,44\% poin terhadap September 2018. Sementara jumlah penduduk miskin pada September 2019 tercatat 24,79 juta orang. 
ABDIMAS: Jurnal Pengabdian Masyarakat Universitas Merdeka Malang Volume 6, No. 2, May 2021: 251-259

Angka tersebut turun 0,36 juta orang terhadap Maret 2019 dan menurun 0,88 juta orang terhadap September 2018. Dalam menghitung angka kemiskinan, BPS menggunakan konsep kemampuan memenuhi kebutuhan dasar (basic needs approach). Namun meskipun secara total kemiskinan turun, tapi masih ada permasalahan tingginya disparitas kemiskinan antara perkotaan dan perdesaan masih tinggi. Persentase kemiskinan di kota pada September 2019 tercatat 6,56\%, sedangkan persentase kemiskinan di perdesaan mencapai $12,60 \%$. Sehingga upaya agar terhindar dari kemiskinan perlu dilakukan oleh masyarakat dimanapun mereka berada. Seperti contoh yang dilakukan oleh beberapa kelompok masyarakat di pedesaan yang tergabung pada peternak ikan lele yang ada di Kampung Coban yang ada di Desa Kanigoro. Sebuah desa bagian dari Kecamatan Pagelaran Kabupaten Malang. Kelompok peternak lele di kampung tersebut menekuni upaya untuk menghasilkan rupiah yang cukup untuk memenuhi kebutuhan hidup keluarganya. Tetapi hal tersebut sulit dilakukan karena beberapa hal, semisal kurangnya informasi dan pengetahuan serta bagaimana beternak lele yang dapat menghasilkan omzet tinggi. Seperti contoh bagaimana memilih bibit lele yang unggul untuk meningkatkan omzet (Aldo, 2019), pembenihan untuk meningkatkan hasil panen ikan (Hernowo \& Suyanto, 2006), dan meminimalisir biaya produksi dengan menggunakan kolam terpal (Mulyani, 2017).

Kesulitan-kesulitan yang dihadapi oleh pengusaha ternak lele mengakibatkan kebangkrutan dan macetnya keberlangsungan usahanya. Seperti tampak pada Gambar 1, yaitu bekas kolam lele milik Bapak Busiri yang usahanya mengalami kebangkrutan akibat masalah-masalah operasional yang tidak dapat diatasi. Sebelumnya, usaha lele yang dilakukan Bapak Busiri berjalan lancar, tapi beberapa panen kemudian mengalami masalah dan pada akhirnya dia memutuskan untuk berhenti menjalani usahanya dan beralih menjadi buruh pembuatan paving milik tetangganya. Pak Busiri berharap bahwa masalah yang dia hadapi tidak menimpa pengusaha ternak lele yang lain dan ada perhatian dari pihak-pihak lain yang bisa membantu untuk keberlanjutan usahanya, semisal dari pemerintah dan atau instansi lain.
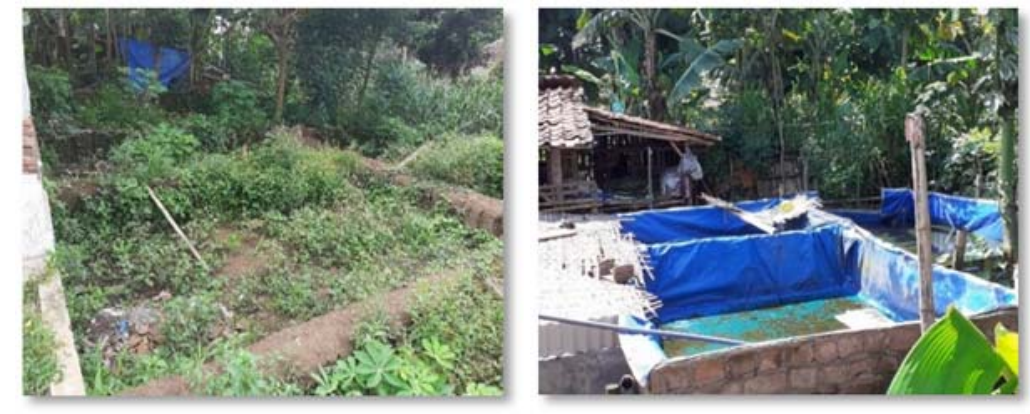

Gambar 1. Bekas kolam lele

Gambar 2. Kolam lele Bapak Sutrisno

Gambar 3. Kolam lele berbau tajam

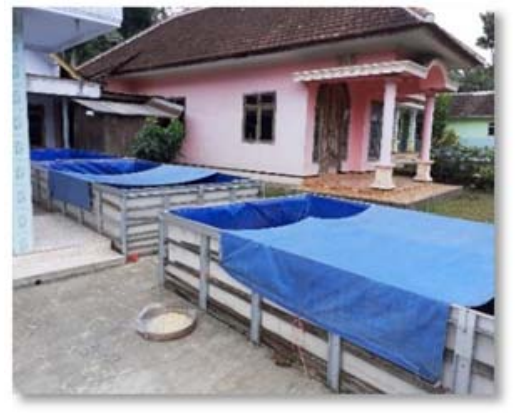

Senada dengan apa yang dialami Bapak Busiri, ada juga peternak lele lain yang masih bertahan walau mengalami kesulitan yang sama dengan Bapak Busiri, yaitu Bapak Sutrisno. Dia bertahan dan tetap menjalani usaha ternak lelenya karena tidak ada pilihan lain walau usaha yang Bapak Sutrisno jalani juga diambang kebangkrutan seperti Bapak Busiri. Pada Gambar 2 ditunjukkan kolam milik Bapak Sutrisno yang telah selesai dipanen, akan tetapi hasilnya tidak seperti yang diharapkan. 


\section{Pelatihan dan Pendampingan Pemeliharaan Ikan Lele Guna Meningkatkan Omzet Penjualan di Desa Kanigoro.. \\ Asroful Anam, Arif Kurniawan, Teguh Rahardjo}

Berbeda dengan apa yang dialami oleh Bapak Sugianto atau yang dikenal Cak Sugi, dia lebih bertahan menjalankan usahanya karena memiliki modal keuangan yang lebih melalui usahanya yang lain, yaitu usaha pemotongan dan penggergajian kayu gelondongan. Sehingga walau memiliki permasalahan operasional yang sama dengan permasalahan yang dihadapi oleh Bapak Busiri dan Sutrisno, Cak Sugi lebih bisa bertahan dengan menyuntikkan hasil usaha kayunya untuk mendukung usaha lelenya. Sehingga walau usaha ternak lele yang ia jalani mendapatkan keuntungan yang sedikit atau tidak seimbang dengan dana operasional, semisal biaya benih, pakan, dan biaya operasional yang lain. Pada gambar 3 ditunjukkan kolam milik Cak Sugi, yang posisi kolamnya berada di sisi rumahnya. Usaha lele yang dijalani Cak Sugi ini menimbulkan masalah bagi tetangga sekitar, karena air dari kolamnya berbau tajam dan membuat tetangga sekitar atau orang yang melewati rumahnya mengeluhkan bau air kolam lele yang ia miliki.

Berdasarkan permasalahan-permasalahan yang dihadapi kelompok peternak ikan lele dalam menjalani usahanya, maka perlu adanya penyelesaian guna meningkatkan pendapatan usaha agar masyarakat yang ada di Kampung Coban, Desa Kanigoro agar dapat terhindar dari kemiskinan melalui program pengabdian masyarakat yang di adakan oleh tim para dosen ITN Malang untuk dapat berperan secara aktif dalam pembangunan nasional sesuai dengan fungsinya yaitu sebagai lembaga pendidikan dan pengembangan IPTEK, terutama di program pengabdian masyarakat (abdimas), yang ruang lingkupnya bisa ke wilayah kabupaten (Panduan PPM, 2020). Peran ITN Malang melalui tugas pokok dosen dalam mendukung program pembangunan pemerintah dalam proses pemberdayaan pembangunan berupa beberapa program seperti: (1) Menumbuh kembangkan dan mempertahankan hidup gotong royong yang selama ini mulai pudar; (2) Membina dan memberikan tambahan bekal ilmu pengetahuan dan ketrampilan; dan (3) Mendorong pemantapan fungsi-fungsi keluarga khususnya di wilayah Kabupaten Malang secara keberlanjutan dalam bingkai pemberdayaan (Propenas, 2000).

Menurut Suryono (2010), konsep pemberdayaan merupakan suatu proses dimana masyarakat (khususnya bagi masyarakat yang kurang akses pada sumber-sumber daya pembangunan) harus didorong untuk meningkatkan kemandiriannya dalam mengembangkan penghidupannya. Sehingga dalam pelaksanaan Program Pengabdian Masyarakat bagi dosen ITN Malang, kegiatan disesuaikan dengan kebutuhan dan permasalahan yang dihadapi masyarakat agar pelaksanaan kegiatan abdimas bisa berdampak positif dan bermanfaat, baik bagi masyarakat, pemerintah, tim pelaksana, dan maupun bagi ITN Malang.

Secara khusus, permasalahan-permasalahan yang dihadapi oleh peternak ikan lele yang ada di Kampung Coban, Desa Kanigoro, Kecamatan Pagelaran, Kabupaten Malang hampir sama dengan peternak-peternak yang ada di daerah-daerah lain. Kelompok wirausahawan peternak lele yang ada di Kampung Coban telah berusaha secara maksimal dan berupaya menghasilkan rupiah yang cukup untuk memenuhi kebutuhan hidup keluarganya. Tetapi hal tersebut sulit dilakukan karena beberapa hal seperti, kurangnya informasi dan pengetahuan serta bagaimana beternak lele yang dapat beromzet tinggi. Contohnya bagaimana memilih bibit lele yang unggul, pembenihan, dan meminimalisir biaya produksi. Pemilihan bibit lele yang unggul untuk pembenihan atau pembesaran seperti lele dumbo merupakan salah satu penentu untuk mendapatkan hasil panen yang sesuai harapan, disamping faktorfaktor yang lain (Walunguru, 2019). 
ABDIMAS: Jurnal Pengabdian Masyarakat Universitas Merdeka Malang

Volume 6, No. 2, May 2021: 251-259

Permasalahan yang dihadapi oleh peternak lele di Kampung Coban, Desa Kanigoro, Kecamatan Pagelaran, Kabupaten Malang terangkum pada 3 aspek, yaitu: (1) Produksi atau masa panen ikan lele, yaitu permasalahan yang diakibatkan karena biaya pakan dipasaran atau pabrikan yang mahal. Harga pakan yang mahal tersebut membuat peternak ikan lele mengurangi pemberian pakan pada ikannya atau tidak sesuai kebutuhan yang seharusnya (Karyana, 2011). Sehingga hal tersebut mengakibatkan masa panen lebih lama dan hasil panen atau produksi ikan tidak sesuai harapan (Sundari et al., 2011); (2) Pemasaran, yaitu permasalahan yang diakibatkan karena kurangnya pengetahuan yang disertai keterampilan bagaimanan cara menentukan bibit yang unggul dan bagaimana cara pembenihan ikan lele yang baik. Sehingga hal tersebut mengakibatkan para tengkulak ikan lele menyortir beberapa ikan dan membuat peternak kesulitan memasarkan ikan lele sortiran (Situmorang, 2016); (3) Manajemen, yaitu permasalahan yang diakibatkan karena minimnya pengetahuan dan keterampilan dalam mengelola usaha ternak ikan lele yang menguntungkan, terutama yang berkaitan dengan biaya operasional usaha peternakan. Sehingga hal tersebut menyebabkan biaya yang harus dikeluarkan oleh para peternak ikan lele sangat besar dan tidak seimbang dengan keuntungan yang didapat jika dikonversi dengan waktu, dan tenaga yang dikeluarkan (Robby et al., 2015).

Tujuan dan manfaat penerapan IPTEK pada program Pengabdian Kepada Masyarakat turut mencerdaskan kehidupan bangsa dan mengantarkan kehidupan berbangsa yang adil dan makmur sebagaimana yang diamanatkan dalam Pancasila dan Undang-Undang Dasar Republik Indonesia Tahun 1945 dengan cara memberi perhatian dan dukungan serta solusi atas permasalahan-permasalahan yang dihadapi oleh peternak lele berupa pembinaan, pelatihan, dan pendampingan kepada peternak ikan lele di Kampung Coban yang ada di Desa Kanigoro Kecamatan Pagelaran Kabupaten Malang. Sehingga masyarakat yang tergabung di kelompok peternak lele di kampung atau desa tersebut dapat memperbaiki derajat kesejahteraan keluarganya.

\section{METODE}

Metode pelaksanaan Program Pengabdian Masyarakat Institut Teknologi Nasional Malang di Kampung Coban, Desa Kanigoro, Kabupaten Malang didasarkan pada metode pendekatan sosial interaktif, yaitu berupa survei langsung dan studi lapangan yang dilakukan tim pelaksana program abdimas serta data hasil beberapa kunjungan terkait permasalahan-permasalahan yang dihadapi masyarakat dikaji dan dibahas antar tim pelaksana, terutama kelompok masyarakat yang yang menjalani usaha ikan lele berikut potensi yang ada di kampung tersebut.

Proses pendekatan dilakukan melalui beberapa forum interaktif salah satunya di rumah kelompok peternak ikan lele. Dari metode pendekatan sosial interaktif ini, ditemukan banyak kesamaan pandangan dan pemikiran, rasa saling melengkapi satu sama lain, bersahabat, dan nyaman. Pada proses pertemuan di forum interaktif baik formal maupun non-formal banyak didapati hal-hal positif, tidak hanya berguna bagi masyarakat sekitar bahkan juga menambah wawasan dan hal baru yang belum diketahui oleh tim pelaksana program pengabdian masyarakat Institut Teknologi Nasional Malang dengan mengkaitkan keadaan lingkungan sekitar yang mungkin dapat mendongkrak kehidupan yang lebih baik dan dapat mengurangi tingkat kemiskinan. 
Setelah beberapa pertemuan dan hasil pendekatan dengan masyarakat serta potensi yang ada di Kampung Coban, Desa Kanigoro, Kecamatan Pagelaran, Kabupaten Malang, muncul kesepakatan dengan kelompok peternak ikan lele. Dari situ, disusunlah langkah-langkah pelaksanaan program abdimas oleh tim pelaksana program pengabdian masyarakat Institut Teknologi Nasional Malang sebagai berikut: (1) Merencanakan alat pembuatan pelet ikan lele yang mandiri untuk mengurangi biaya operasional. Pakan lele yang dibuat sendiri akan meningkatkan omzet pada panen ikan (Nugroho et al., 2019); (2) Merencanakan konsep dan rencana untuk membantu kelompok peternak ikan lele dengan fokus pada upaya dan usaha menyelesaikan permasalahan-permasalahannya dihadapi oleh peternak lele di Kampung Coban dengan cara memberikan pembimbingan dan pengarahan secara total bagaimana cara menentukan dan memilih bibit lele yang unggul dan beromzet tinggi; (3) Membuat perencanaan dan pelaksanaan pendampingan dan monitoring secara berkesinambungan bagaimana cara pembenihan ikan lele yang baik dan terampil; (4) Membuat checklist target hasil yang berkaitan dengan pembimbingan, pendampingan, dan konsolidasi secara tuntas dalam meningkatkan kemampuan para peternak ikan lele tentang tata kelola operasional bidang usaha ternak lele yang menguntungkan; (5) Membuat perencanaan terstruktur sebagai upaya bagaimana membangkitkan kembali semangat peternak lele yang mengalami kebangkrutan untuk menjalankan usaha ternak lelenya sebagai usaha utama untuk mendapatkan keuntungan ekonomi yang memadai, dan (6) Membuat perencanaan terstruktur sebagai upaya bagaimana menanggulangi pengangguran dan memperdayakan masyarakat yang tidak berpenghasilan untuk sama-sama berwirausaha dan mengurangi angka kemiskinan di pedesaan, khususnya menjadi peternak lele yang handal. Dengan upaya pemberdayaan tersebut, potensi kemiskinan dapat diantisipasi (Indika \& Marliza, 2019)

Langkah-langkah pelaksanaan program Abdimas oleh tim pelaksana program pengabdian masyarakat Institut Teknologi Nasional Malang di Kampung Coban, Desa Kanigoro, Kecamatan Pagelaran, Kabupaten Malang dengan metode ini, tim meyakini bahwa permasalahan-permasalahan yang dialami oleh peternak ikan lele dapat teratasi dengan baik dan sesuai perencanaan serta target yang hendak dicapai. Sehingga seluruh kelompok peternak ikan lele dapat meningkatkan hasil panen ternak lelenya dan dapat meningkatkan kesejahteraan hidup keluarganya serta dapat mengurangi tingkat kemiskinan.

Sedangkan IPTEK pada pelaksanaan program pengabdian masyarakat di Kampung Coban, Desa Kanigoro, Kabupaten Malang, disamping pembinaan berupa bimbingan dan pendampingan terkait bagaimana menentukan bibit unggul, pembesaran, desain kolam dengan biaya hemat, dan tata kelola usaha yang menguntungkan, yaitu pembuatan pelet pakan lele secara mandiri. Sehingga dengan membuat pakan lele sendiri, diharapkan biaya operasional pembesaran ikan lele dapat menghasilkan keuntungan dan omzet yang tinggi. Pembuatan pakan lele sendiri memanfaatkan limbah makanan rumah tangga yang tidak layak dikonsumsi, semisal sisa penjualan limbah mie ayam, roti, ulat, buah pepaya, dan lain-lain. Bahan pelet pakan lele juga ditambahkan dengan limbah ulat untuk pakan burung dan sayur-sayuran untuk menambah nilai gizi pelet pakan lele. Untuk pembuatan alat pencetak pelet pakan lele, dirancang sendiri dengan memanfaatkan gilingan mie pangsit yang digerakakan oleh motor penggerak dengan rangkan seperti layaknya teknologi tepat guna/TTG. 
ABDIMAS: Jurnal Pengabdian Masyarakat Universitas Merdeka Malang

Volume 6, No. 2, May 2021: 251-259

Bahan-bahan yang diperlukan pada pembuatan alat untuk pembuatan pelet pakan lele mandiri: (1) Gilingan mie pangsit baru atau bekas; (2) Motor penggerak baru atau bekas; (3) Besi untuk rangka; (4) Velt; (5) Pulley; (6) Bearing; (7) Saklar; (8) Kabel; (9) Wadah pelet.

Cara membuat alat pembuatan pelet pakan lele: (1) Desain alat; (2) Pembubutan, pengelasan dan perakitan; (3) Melengkapi komponen-komponen lain yang dibutuhkan untuk perakitan; (4) Uji pengoperasian menjalankan alat; (5) Persiapan bahan-bahan pelet pakan lele; (6) Pengujian pembuatan pelet pakan lele dengan alat; (7) Finishing.

\section{HASIL DAN PEMBAHASAN}

Berdasarkan hasil kegiatan pelaksanaan program pengabdian masyarakat bagi peternak lele di Kampung Coban yang ada di Desa Kanigoro, Kecamatan Pagelaran, Kabupaten Malang, yaitu berupa: (1) Perancangan alat pembuatan pelet pakan lele secara mandiri; (2) Pembimbingan dan pengarahan secara total bagaimana cara menentukan dan memilih bibit lele yang unggul dan beromzet tinggi; (3) Pendampingan dan monitoring secara berkesinambungan bagaimana cara pembenihan ikan lele yang baik dan terampil; dan (4) Pembimbingan, pendampingan, dan konsolidasi secara tuntas meningkatkan kemampuan tentang tata kelola operasional bidang usaha ternak lele yang menguntungkan. Maka didapatkan hasil bahwa peternak ikan lele dapat membuat pakan sendiri yang dicampur dengan pakan pabrikan dan dapat meningkatkan omzet sebagai dampak/nilai manfaat penggunaan alat dan pembinaan dalam pemilihan bibit unggul dan tata kelola usaha ternak ikan lele.

Sedangkan partisipasi kelompok peternak yang tergabung pada kelompok pembuatan pelet lele dan kelompok pembesaran ikan lele pada pelaksanaan kegiatan program pengabdian masyarakat di Kampung Coban, Desa Kanigoro,nKabupaten Malang diharapkan terlibat secara aktif dengan tugas masing-masing, serta seluruh pemuda masyarakat sekitar dapat secara intensif dan disiplin mengikuti seluruh kegiatan yang telah disepakati, agar hal-hal yang menjadi permasalahan peternak di Kampung Coban, Desa Kanigoro dapat teratasi dengan baik dan dapat menjadi sumbangsih ekonomi yang berkelanjutan, demi kehidupan yang lebih mandiri dan sejahtera. Untuk itu, tim berharap bahwa para kelompok peternak akan bertindak berdasarkan pada keuntungan dan kerugian masing-masing yang mereka peroleh selama berinteraksi dengan tim pelaksana selama pelaksanaan program pengabdian masyarakat Institut Teknologi Nasional Malang. Kemudian diharapkan pula masyakat yang terlibat secara bersama-sama dengan tim dapat menyediakan keperluan operasional agar kegiatan dapat berjalan dengan sukses sesuai harapan, meliputi: (1) Akomodasi (konsumsi) selama berlangsungnya kegiatan program abdimas LPPM ITN Malang; (2) Pump, saluran perpipaan, air, bibit lele, dan peralatan di luar solusi yang ditawarkan; (3) Tempat dan peralatan untuk bimbingan konseling dan konsultasi; (4) Beberapa tenaga untuk membantu penyediaan bahan pakan, pembukuan dan operasional; (5) Whiteboard untuk jadwal kegiatan; (6) Kelompok pemuda untuk kader wirausahawan atau peternak pemula.

Kemudian pengembangan IPTEK pada pelaksanaan program pengabdian masyarakat di Kampung Coban, Desa Kanigoro, Kabupaten Malang tertumpu pada penyelesaian-penyelesaian atas permasalahan yang dihadapi oleh peternak ikan lele, yaitu bimbingan dan pendampingan terkait bagaimana menentukan bibit unggul, pembesaran, desain kolam dengan biaya hemat, tata kelola usaha yang menguntungkan, dan pembuatan pelet pakan lele secara mandiri dengan menggunakan mesin atau alat yang mudah dilakukan berupa teknologi tepat guna/TTG. Sehingga dengan membuat pakan 
lele sendiri, diharapkan biaya operasional pembesaran ikan lele dapat menghasilkan keuntungan dan omzet yang tinggi. Berikut adalah beberapa dokumentasi pelaksanaan Program Pengabdian Masyarakat bagi peternak lele di Kampung Coban yang ada di Desa Kanigoro (Gambar 5-12).
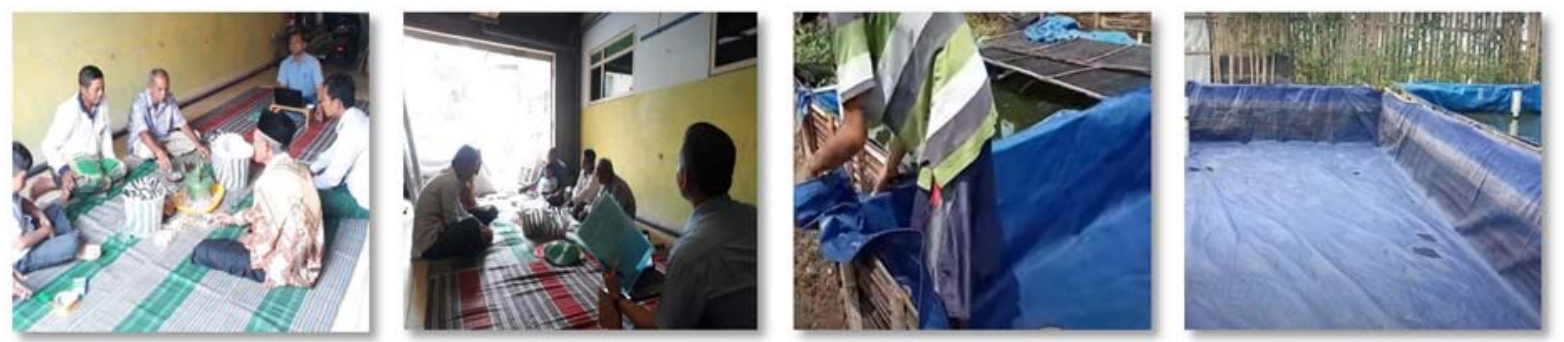

Gambar 5. Sosialisasi dan pertemuan dengan kelompok peternak

Gambar 6. Pembuatan kolam terpal
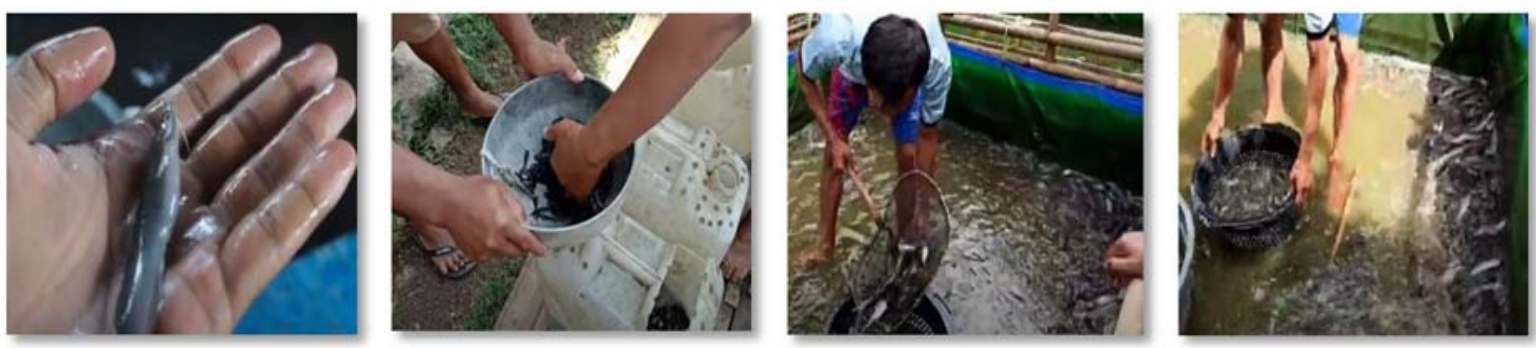

Gambar 7. Pemilihan bibit lele

Gambar 8. Pemanenan ikan lele
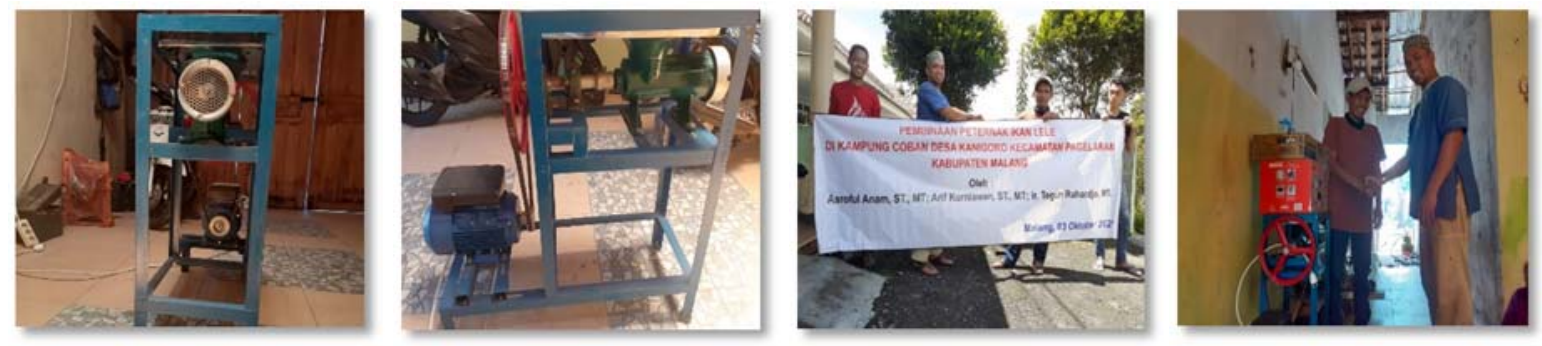

Gambar 9. Alat pembuatan pakan lele

Gambar 10. Penyerahan alat ke ketua kelompok
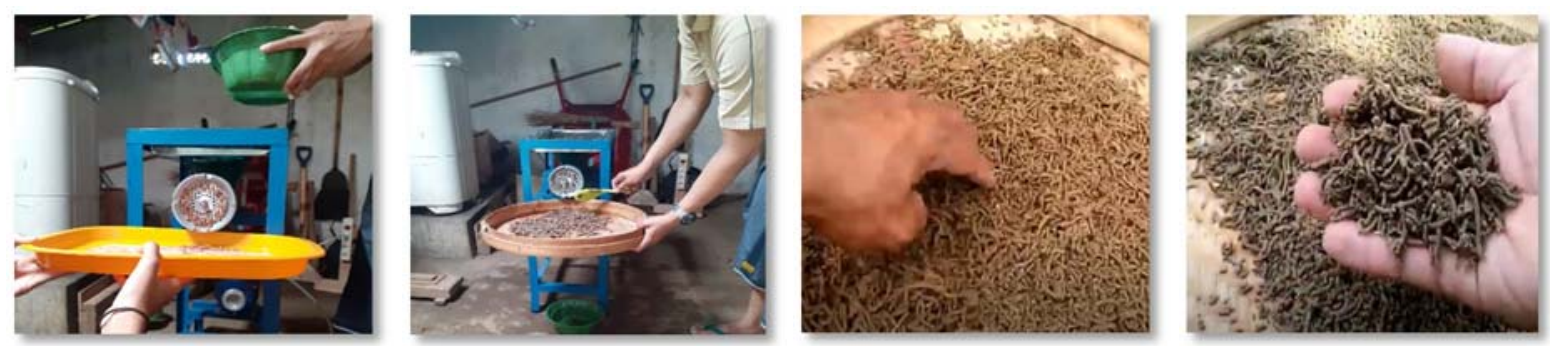

Gambar 11. Penggunaan alat oleh peternak ikan lele Gambar 12. Penjemuran pakan ikan lele 
ABDIMAS: Jurnal Pengabdian Masyarakat Universitas Merdeka Malang

Volume 6, No. 2, May 2021: 251-259

Hasil di atas sesuai dengan target tim pelaksana pada program pengabdian masyarakat LPPM Institut Teknologi Nasional Malang yang telah dibuat adalah merupakan kesepakatan konsep solusi pelaksanaan abdimas berdasarkan permasalahan-permasalahan yang dihadapi masyarakat yang usahanya di bidang peternakan ikan lele di Kampung Coban, Desa Kanigoro, Kecamatan Pagelaran, Kabupaten Malang. Konsep tersebut dikaji bersama tim dosen pelaksana abdimas dan merujuk rencana strategis pelaksanaan penelitian dan pengabdian kepada masyarakat di Lembaga Penelitian dan Pengabdian Masyarakat Institut Teknologi Nasional Malang. Target atau konsep solusi yang hendak dicapai atas permasalahan-permasalahan yang dihadapi peternak lele meliputi: (1) Terciptanya alat pembuatan pelet pakan lele secara mandiri; (2) Terlaksananya program pembimbingan dan pengarahan secara total bagaimana cara menentukan dan memilih bibit lele yang unggul dan beromzet tinggi; (3) Terlaksananya program pendampingan dan monitoring secara berkesinambungan bagaimana cara pembenihan ikan lele yang baik dan terampil; (4) Terlaksananya program pembimbingan, pendampingan, dan konsolidasi secara tuntas meningkatkan kemampuan tentang tata kelola operasional bidang usaha ternak lele yang menguntungkan; (5) Terlaksananya program upaya bagaimana membangkitkan kembali semangat peternak lele yang mengalami kebangkrutan; (6) Terlaksananya program upaya menanggulangi pengangguran dan memperdayakan masyarakat yang tidak berpenghasilan untuk sama-sama berwirausaha dan mengurangi angka kemiskinan di pedesaan.

\section{SIMPULAN DAN SARAN}

Berdasarkan seluruh kegiatan pada program abdimas oleh tim pelaksana program pengabdian masyarakat Institut Teknologi Nasional Malang dengan sasaran kelompok peternak ikan lele, maka dapat disimpulkan bahwa sebagai berikut: (1) Hasil produksi atau panen ikan lele meningkat dengan penggunaan pakan yang dibuat sendiri walau pakan tersebut dicampur dengan pakan pasaran untuk menjaga asupan nilai gizi yang harus diberikan kepada ikan; (2) Masa panen lebih cepat karena skala pemberian pakan sesuai kebutuhan; (3) Peternak tidak kesulitan lagi memasarkan hasil panen ikan lelenya karena telah memiliki pengetahuan dan keterampilan bagaimanan menentukan bibit yang unggul dan bagaimana cara pembenihan ikan lele yang baik; (4) Peternak memiliki keterampilan manajerial usaha yang lebih baik berupa kemampuan dan pengetahuan mengelola usaha ternak ikan lele yang lebih menguntungkan, mulai dari perencanaan, pelaksanaan, dan waktu panen ikan lelenya.

Keterbatasan-keterbatasan pada pelaksanaan program pengabdian masyarakat ini diantaranya: (1) Ditemukannya pakan lele yang dibuat masih harus dicampur dengan pakan lele pasaran atau pabrikan, karena jika tidak dicampur menyebabkan masa panen sedikit lebih lama; (2) Minimnya waktu dan referensi tim pelaksana terkait kandungan nilai gizi dari bahan baku pakan, karena pakan yang dibuat beberapa berasal dari limbah ulat, mie kadaluarsa, dan roti tidak layak konsumsi; dan (3) Sulitnya mencari salah satu bahan baku pakan lele, karena pencampuran dari bahan-bahan baku pakan lele tidak melalui kajian terlebih dahulu. Sehingga saran-saran untuk pelaksana program pengabdian masyarakat Institut Teknologi Nasional Malang berikutnya atau para institusi lain adalah perlu adanya program abdimas yang fokus pada bahan-bahan pakan yang dapat menambah nilai gizi pelet pakan ikan lele dan dapat mempercepat waktu panen ikan lele serta meningkatkan omzet dan keuntungan bagi kelompok peternak agar kehidupan masyarakat di pedesaan lebih sejahtera dan makmur. 


\section{DAFTAR PUSTAKA}

Aldo, D. (2019). Pemilihan bibit lele unggul dengan menggunakan metode weighted product. Jurnal Teknologi dan Open Source, 2(1), 15-23. https://doi.org/10.36378/jtos.v2i1.138

Badan Pusat Statistik (BPS). (2019). \%tase Penduduk Miskin di Indonesia [Artikel Web]. Badan Pusat Statistik. Retrieved from: https://www.bps.go.id/pressrelease/2019/07/15/1629/\%tasependuduk-miskin-maret-2019-sebesar-9-41-\%.html

Hernowo, H., \& Suyanto, R. (2006). Pembenihan dan Pembesaran Lele di Pekarangan, Sawah, dan Longyan. Jakarta: Penebar Swadaya.

Indika, M., \& Marliza, Y. (2019). Upaya pemberdayaan Usaha Mikro Kecil Menengah (UMKM) dalam mengatasi kemiskinan di Kecamatan Tugumulyo Kabupaten Musi Rawas. MBIA: Journal Management, Business, and Accounting, 18(3), 49-66.

https://doi.org/10.33557/mbia.v18i3.598

Karyana, K. S. (2011). Pengaruh kenaikan harga pakan terhadap permintaan pakan, produktivitas dan pendapatan usaha pembesaran ikan nila pola kolam air deras. Paspalum: Jurnal Ilmiah Pertanian, 1(2), 74-84. https://doi.org/10.35138/paspalum.v1i2.84

Nawangsih, N. (2018). Sosialisasi manajemen usaha produktif untuk meningatkan pendapatan dan kesejahteraan keluarga. Jurnal Empowerment Society, 1(02), 37-46.

https://doi.org/10.30741/eps.v1i02.306

Nugroho, A. S., Rahayu, A. T., \& Kristiawan, Y. Y. (2019). Peningkatan hasil ternak lele dengan pengolahan pakan plus secara mandiri. Suluah Bendang: Jurnal Ilmiah Pengabdian kepada Masyarakat, 19(3), 135-143. https://doi.org/10.24036/sb.0190

Mulyani, M. (2017). Analisis pendapatan usaha budidaya ikan kolam terpal di Kecamatan Rimbo Ulu. Jurnal MeA (Media Agribisnis), 2(1), 28-34. https://doi.org/10.33087/mea.v2i1.15

Panduan PPM. (2020). Panduan Penelitian dan Pengabdian Masyarakat [Artikel Web]. LPPM ITN Malang.

Propenas. (2000). Undang-Undang Nomor 25 Tahun 2000 tentang Program Pembangunan Nasional.

Robby, A. N., Arsyad, A., \& Yusdiarti, A. (2015). Analisis pendapatan dan faktor-faktor produksi yang mempengaruhi usaha budidaya pembenihan ikan lele dumbo di Kecamatan Ciseeng Bogor. Jurnal AgribiSains, 1(1), 30-37. https://doi.org/10.30997/jagi.v1i1.175

Situmorang, B. (2016). Efisiensi pengiriman benih ikan lele dumbo (Clarias gariepinus) dengan kepadatan yang berbeda dalam packing Tukka-Kota Pinang. JOISH: Jurnal Ilmu Sosial dan Humaniora, 5(2), 817-827. https://doi.org/10.23887/jish-undiksha.v5i2.8644

Sundari, S., Nugroho, E., \& Subagja, J. (2011). Pengaruh frekuensi pemberian pakan pada pendederan ke dua ikan lele dumbo yang dipelihara di kolam tanah. Sains Natural: Jurnal Ilmiah Ilmu-Ilmu Biologi dan Kimia, 1(1), 1-6. https://doi.org/10.31938/jsn.v1i1.5

Suryono, A. (2010). Dimensi-Dimensi Prima Teori Pemberdayaan Pembangunan. Malang: Universitas Brawijaya Press

Walunguru, L. (2019). Optimalisasi usaha ternak lele dan ayam pedaging melalui pemeliharaan yang intensif. J-Dinamika: Jurnal Pengabdian Masyarakat, 4(1), 39-45.

https://doi.org/10.25047/j-dinamika.v4i1.1050 